\title{
The Use of Reinforcement in Writing and Speaking Skill for Adult Learners in Mahasaraswati University
}

\author{
${ }^{1 s t}$ Ni Wayan Ita Sari \\ Post Graduate Program, English Language \\ Education \\ Ganesha University of Education \\ Denpasar, Bali, Indonesia \\ itasari.niwayan@gmail.com
}

\author{
${ }^{2 n d}$ Ni Luh Putu Tini Paradina \\ Post Graduate Program, English Language Education \\ Ganesha University of Education \\ Denpasar, Bali, Indonesia
}

\begin{abstract}
The purpose of the study was to find out the use of the use of reinforcement in writing and speaking skill for adult learners in Mahasaraswati University. The study employed qualitative method which qualitative data was collected. The subject of the study was the lecturers of Mahasaraswati University who taught Basic Writing and Speaking Skill. The data was collected by using questionnaires and interviews. The findings of the study were show that the teachers used positive reinforcement in teaching writing skill to adult learners and it affected the learners' motivations. In addition, the teachers also use positive reinforcement to teach speaking skill. The students' motivations enriched after implementing reinforcement and they can perform better in speaking performance.
\end{abstract}

Keywords: Adult Learner, Writing Skill, Speaking Skill, Reinforcement.

\section{INTRODUCTION}

Reinforcement in learning was used by educationists of the ancient Greeks (Cotton, 2008). Appropriate classroom behavior is maintained for many students in the classroom by naturally occurring reinforcers such as positive attention from the teacher, grades, or selfreinforcement that results from task completion. However,

these naturally occurring reinforcers may not be sufficient to maintain all desirable behaviors in all students. It is frequently necessary to look for more powerful reinforcers. Teachers should use caution in selecting and using positive reinforcers. Reinforcers should be age appropriate, and the use of "natural" reinforcers is encouraged whenever possible.

Tangible and edible types of rewards were given to children on order to acquire study habits and to like learning. Like in the olden times, instructional reinforcement in classroom teaching is still in use (Alberto \& Troutman, 2006). Instructional reinforcement is of great importance and interest to teachers since it provides clues to the reason for academic success or failure for learners in schools. In teaching, success occurs when desired behavior is adequately reinforced (Slavin, 2009). The idea that learning can be stimulated and enhanced through the use of reinforcers dates back as far as the educational practices of the ancient Greeks (Bandura, 2008). Learning has always held a high place in many societies all over the world (Slavin, 2009).

Reinforcement learning (RL) was initially designed by the psychologists and has been studied for almost a century. It was then reused by the Machine Learning community. Up until today, a clear synthetic view of the approach allowing each variation of the implementation to be positioned has not been available. By decomposing existing reinforcement learning methods into functions and elements, we are able to propose a general model of the reinforcement approach. Instantiations of this general model on the widely used Q-Learning and its refinements allow us to easily understand a neural implementation of reinforcement and to point out the advantages and disadvantages of this approach. Furthermore, we can determine where our efforts should be made so as to improve the performance of a neural implementation of reinforcement.

The terms reward and reinforcement have frequently been used synonymously. Although this is the case, behavioral psychologists make an important distinction between the two terms. A reinforcer is an event that increases the frequency of the behavior it follows. A reward, however, is not defined by its effects on behavior. Rewards are stimuli that are assumed to be positive events, but they have not been shown to strengthen behavior.

Behavior management strategies using differential reinforcement are effective only if the reinforcement procedures match the individual's unique characteristics and needs. Simply stated, the individual must find the reinforcer reinforcing. Errors in achieving this match frequently sabotage the success of otherwise well-designed 
intervention plans. The educator or the teacher will need to determine appropriate reinforcers for the student as well as the frequency and manner in which they are given. Besides, based on the observation in Mahasaraswati University, the researcher found that in the second semester of English Education Study Program implements reinforcement in teaching writing and speaking skill for adult learner. It is very important to use reinforcement in teaching adult learner.

To sum up, based on the observation that was done, the researcher interest to conduct a study about the implementation of reinforcement in teaching writing and speaking skill for adult learner in Mahasaswati Denpasar University for the second semester students who is taught by the teacher which is used reinforcement in the teaching and learning process.

Research Problem

As what has been mentioned above, the use of reinforcement in teaching and learning process is very important for adult learner, especially in teaching writing and speaking. In this present study, the researcher formulated some research problems which was found from the observation that was done by the researcher. Thus, the research problem discussed in this study will be formulated as follows:

1. How is the frequency of using reinforcement in teaching English?

2. What are the teacher's preparation in using reinforcement in teaching English?

3. What are the types of reinforcement that use by the teacher in teaching writing and speaking for adult learner?

\section{Theoretical Framework and Literature Review}

\footnotetext{
Reinforcement

Reinforcement theory has been used in many areas of study among them animal training, raising children and teaching learners. According to Moore (1989) stated that reinforcement or the rewarding of desire student behavior, is a long recognized and essential skill for classroom teachers. Reinforcement theory focuses on observable behavior such as learning in the classroom. There are various primary approaches to reinforcement theory. Wolkfolk (1987) in Moore (1989) said that there are two types of reinforcement. They include positive reinforcement and negative reinforcement. Reinforcement is something that happens after a behavior that makes it more likely to occur again. Different types of reinforcers may be used to motivate different students, but it is important to make clear to the student under what conditions a reward can be acquired. The techniques of behavior modification are based on operant conditioning; the focus is on rein-forcing desirable behaviors and ignoring undesirable ones. This approach has a major role in special education being used both to create effective teaching methods and to control behavioral problems. It is
}

also used to improve functional skills deficits, promote self- management, and train teachers.

Teachers can teach appropriate behavior and improve the classroom environment by the use of positive reinforcement; however, many teachers do not have the skills to manage their classrooms. Strong classroom management skills are essential for effective teaching. Moore states that using praise and positive reinforcement can decrease the students' inappropriate behavior as well as increase appropriate behavior and response to teachers' demands.

Through the use of positive reinforcement, teachers can improve their students' motivation to behave appropriately (Lepper et al., 2005). Social reinforcements, such as attention, appreciation, and appropriate praises, are often more rewarding than toys or food for students. Putting a hand on a student's shoulder, using encouraging words in front of others, a nod, or an approving smile can be very meaningful (Michigan Team Nutrition, 2004). Students with additional learning needs require encouragement and attention more than their nondisabled peers, hence giving more attention in the classroom while completing assignments will help their progression.

Rewards should be provided to learners based on standards performance. However, the extrinsic reinforcers such as grades or tangible rewards may influence students to learn just to get the rewards. This shows that the use of such types of reinforcers should only be used if they are effective and if they make a difference to the dynamics of students. Wong and Wong (2009) suggest that whole class reinforcers are the most effective in reinforcing classroom learning. However, teachers should explain to students that they do not merely receive reinforcers; rather, they should earn them. Therefore, reinforcement strategies in classroom teaching are important factors that influence school learning. Instructional reinforcement strategies are significant to a successful teacher's delivery of instruction.

\section{Adult Learner}

Adult learning is defined as 'the entire range of formal, non-formal and informal learning activities which are undertaken by adults after a break since leaving initial education and training, and which results in the acquisition of new knowledge and skills. The European Commission defines adult learning as, 'all forms of learning undertaken by adults after having left initial education and training, however far this process may have gone (e.g. including tertiary education).' (European Commission 2006b, p. 2).

Adult learner (mature student) is a term used to describe any person socially accepted as an adult who is involved in a systematic learning process, be it formal or non-formal or informal. This process maybe self-mentored or corporate- sponsored; where learning may be undertaken as fulltime or a part time learner. Adult learners comprise of a diverse group of people belonging to different genders, caste, class, religion, region, majority or minority groups, creed, race, ethnicity varying from each other in their needs, problems, requirements, attitudes and outlook towards life. Unlike a child learner the adult learner is 
autonomous and comes voluntarily to the learning situation. Since the adult learners are very clear about the results they anticipate from the learning process they may drop out of learning activities if their expectations aren't met.

The term 'andragogy' is derived from Greek words meaning "man-leading" and it is distinguished from pedagogy which means "child-leading". Andragogy was originally coined by the German educator Alexander Kapp in 1833 (Knowles, 1990) and it was developed as an adult education theory by Malcolm Knowles, an American educator.

Andragogy is an art and science which helps the adults to learn (Knowles, 1970, p.38). The theory believes that an individual becomes psychologically an adult where the individual at that point accomplishes a self-concept of necessary self- direction. When this occurs a very critical thing happens: at this stage a deep psychological need of an individual develops which is visible to others as being self-directing. Hence, when an individual himself is aware of a situation during which he is not permitted to be selfdirected then he experiences pressure and stress between the situation and his self-concept. As a result of this situation the individual is bound to be ruined with anger and disagreement (Knowles, 1978, p.56).

There are some similarities in the adult and child classroom although adults generally have distinctly different motivations to engage in learning. Adult learning theory is founded on the principles that effective training is:

1. Relevant

experience or intended experience of the adult learner. Whereas children and adolescents will attempt to learn content isolated from its application, adults learn best when they see the relevance of the taught concept to their experience

2. Engaged

the adult learner retains knowledge and concepts more readily if they are engaged in the process of discovery and exploration rather than being the recipient of information

3. Active

the learning process should be active, and replicate as closely as possible the environment within which the skill or knowledge will be applied. Rather than memorizing code sections, adults would retain and apply knowledge more effectively if they worked to discover the content, and then were able to practice its application in a simulation or scenario.

4. Learner- centered

The traditional classroom taught concepts and prepared students to pass tests and other measures of their progress. Unfortunately, the student's retention of that knowledge was often nominal beyond the confines of the class. The emerging intent of police academy training is to produce the most effective outcomes possible; to see students aply classroom skills in a real- world setting. The focus on the learner acquiring knowledge, is a critical step in effective training

The two theories that have a significant influence on adult teaching and learning are those of Malcolm Knowles and Paulo Freire. Knowles attempted to develop adult education and learning by popularizing the notion of andragogy, which became widely discussed and used. His work was a significant factor in reorienting adult educators from educating people to helping them learn. Knowles was the first person to chart the rise of the adult education movement in the United States, and the first person to develop a statement of informal adult education practice via the notion of andragogy.

The education of adults should recognize the experience of learners and use that experience as a resource for teaching and learning. Learners have to be self- directed, motivated volunteers of learning and cannot be forced. It is important to equip learners with motivation and skills for lifelong learning. The learners should be engaged in informal learning activities where they share and learn by doing. The education should recognize and respect readiness to learn.

The learners should practice and refine the things learnt. There is a saying that practice makes perfect. The learners should be made to know why they should learn particular skills. Freire made many important contributions to the fields of adult education. Freire's evolving thinking was on the learner- centered approach. Freire views teaching as a political process, as an act of knowing and as a creative act.

According to Freire, everyone knows something and the learner is responsible for the building up of knowledge and for the re-signification of what he/she learns. For Freire, the human learns through his/her own transforming action in the world (transformational learning). It is the learner who constructs his/her own categories of thought, organizes his/her life and transforms the world.

Knowles (1984) suggests that adult educators should:

- Set a cooperative climate for learning in the classroom;

- Assess the learner's specific needs and interests;

- Develop learning objectives based on the learner's needs, interests, and skill levels;

- Design sequential activities to achieve the objectives;

- Work collaboratively with the learner to select methods, materials, and resources for instruction; and

- Evaluate the quality of the learning experience and make an adjustment, as needed, while assessing needs for further learning.

The literature additionally suggests that adults will be more motivated, and more successful at learning, when they have some say in what they are being taught. Therefore, it is frequently recommended that teachers of adults follow a learner- centered model of instruction, which is to say that the teacher should identify the learners' needs and interests in learning and incorporate these into his or her lesson planning, and allow the learners to learn from each other as much as, or even more than, the 
teacher. The instructor should see him- or herself as a partner in the students' learning process, rather than as an absolute authority, and the curriculum should be developed as a collaboration between the learner and the teacher. Also, adults usually bring a wealth of personal experience to the classroom that younger learners do not have. This brings both advantages and disadvantages. The advantages are that adult learners already possess the knowledge of how to learn, in many cases how to behave in the classroom, and have some ability to self- discipline. The disadvantage is that they may have pre-conceived notions about education that may run counter to the teacher's own teaching methods.

Even though learners may be more accustomed to a teacher-centered classroom, a learner-centered class is generally recommended. This includes activities such as pair- and group-work, as they allow the adults to take more responsibility for their own learning and incorporate the teachers as partners, rather than authorities. Project-based learning is also often recommended, as it allows adults to pursue their own interests during the process of studying English. Furthermore, authentic material should be incorporated wherever possible, as this material relates more directly to the adult learner's daily lives (Moss \& Ross- Feldman, 2003).

\section{Classroom Management}

Classroom management has been one of the most serious challenges facing English as a Foreign Language (EFL) teachers. Brophy (1988) defined classroom management as "the actions taken to create and maintain a learning environment conducive to attainment of the goals of instruction-arranging the physical environment of the classroom, establishing rules and procedures, maintaining attention to lessons and engagement in academic activities". In other words, it refers to the actions taken by teachers in creating a facilitative environment for both academic and social emotional learning (Everstone \& Weinstein, 2006).

There are three main dimensions to the construct of classroom management, namely instructional management, people management, and behavior management. Instructional management relates to the approach teachers use to establish general classroom atmosphere and refers to the teachers' styles of classroom management (McNeely \& Mertz, 1990). People management concerns with the extent and quality to which teachers develop and nurture teacher-student relationships (Weinstein, 1996). Behavior management pertains to the prevention of misbehavior and provides opportunities for student input as well as a reward system for appropriate behavior (Martin, Yin, \& Baldwin, 1998).

Several models of classroom management have been developed over the past few decades. Glickman and Tamashiro (1980), for instance, conceptualized one of the most popular frameworks to explain teacher beliefs toward classroom management. It consists of three approaches, they are interventionist, non- interventionist, and interactionalist. Interventionists refers to the teachers who believe that students learn appropriate behaviors primarily when their behaviors are reinforced by teacher generated rewards and punishments and exercise a high degree of control over classroom activities. Non-interventionist teachers, on the other hand, believe that students have an inner drive that needs to find its expression in the real world and allow students to exert significant influence in the classroom and teachers should be less involved in adjusting student behaviors. Last, interactionalist teachers, students learn appropriate behaviors as a result of encountering the outside world of people and objects. Therefore, they believe that students and teachers should share responsibility for classroom management.

Classroom management refers to teacher behaviors that facilitate learning. A well-managed classroom increases learning because students spend more time on tasks. Classroom management is a prerequisite for achieving instructional objectives and safeguarding the well - being of students for whom the teaching and learning activities are centered (Ogunu, 2000). Classroom management entails planning, supervising, controlling and coordinating the activities of pupils in teaching -learning process. According to Grieser (2007), successful classroom management enhances students questioning and exploration only Classroom management is a prerequisite for achieving instructional objectives and safeguarding the well - being of students for whom the teaching and learning activities are centered (Ogunu, 2000). Classroom management entails planning, supervising, controlling and coordinating the activities of pupils in teaching - learning process. According to Grieser (2007), successful classroom management enhances students questioning and exploration only.

Finally, a classroom management that has made a significant impact on the scope in the process of transferring the knowledge to the learners. It can be concluded that learning outcomes are directly related to the learning environment within the classroom created by the teacher due to the fact that the processes of learning that they foster are by far the more powerful.

\section{Writing Skill}

Writing is an important form of communication in day to day life, but it is especially important in high school and college. Writing is also one of the most difficult skills to master in both a first language and a second language. Even though in our daily life people always communicate orally, written form will help people communicate in some cases directly or indirectly (Zemach and Islam, 2005).

According to Nunan (2003:88), writing is the process of thinking to invent ideas. It thinks about how to express ideas into good writing and arranges the ideas into statement and paragraph clearly. It indicates that the learners are expected to explore the ideas and make them into a good paragraph. Besides, writing is both a mental and a physical act. It is the physical act of committing words or ideas to some medium whether it is an object or a symbol or a mental. 
Writing is not a linear or step by step procedure but a frequently messy process of an adventure. Furthermore, Lewis and Hurd (2008:103) states that writing consists of levels of structures. It is started from words to phrase, clause to sentences and the sentences to paragraph or essay. However, following the conventions in the "science", the writing in these reports is generally taken being minimally expressive. As a result, discovered phenomenon can be reflected as clearly as possible in the text (Golden et al., 2007:10). However, according to Patel and Jain (2008:125), writing is a kind of linguistic behavior. It presents the sounds of language through visual symbols. Consequently, writing may be very important for one group of students but much less important for others. Writing is one of the hardest skills that everybody cannot always do so that everybody should learn the process of writing a good paragraph. According to Kalandadze (2007:5), the process of writing generally consists of the following stages such as pre-writing, drafting, and revising. In the pre-writing, writers take time to think about their topic and generate ideas. Besides, they also spend time to focus and plan about the content of their paragraph. Next in the drafting, the writers write down the plans or ideas into a sequence and provide the readers to understand about the meaning about these ideas. The last is revising, writers do some processes that their writing will be corrected by someone who is skillful in writing. As a result, their writing will be better than before after revising.

Brown (2004:220) states that writing has four categories that capture the range of written production that should be considered. Each category resembles the categories defined for the other three skills, but these categories as always reflect the uniqueness of the skill area. The four categories are imitative, intensive, responsive, and extensive. In imitative, the learners have to attain skills in the fundamental, basic task of writing letters, words, punctuation, and very brief sentences. In intensive, the learners focus on the meaning and context which are the point to create the correct and appropriate paragraph. In responsive, the learners learn how to connect sentences into paragraph and create a logical connected sequence of two or three paragraphs. In extensive, the writers focus on achieving a purpose, organizing, and developing ideas logically; as a result, the final product is engaging in the process of multiple drafts.

Kane (2002:34) states that writing is not an easy product that the writer can do without any steps, to make it easier the writer should follow the following steps such as: prewriting, planning, drafting, revising, and writing. Prewriting is the first stage in the writing process, in which in this step the writer chooses a topic to start to write a paragraph. In addition, planning (outlining) is to organize the ideas the learners generated by brainstorming in an outline. On the other side, there are two steps in planning: they are constructing outlining and writing the topic sentence. The next step in writing is drafting in which this is the basic step in writing good paragraphs. Then, writing and revising the draft in this stage will be done by the writers by doing three steps such as: writing the first rough draft, revising content and organization, and proofreading the second draft. Writing the final copy to hand is the last step in writing. As the final step in writing process, writers have to rework the written drafts and polish them for the publication and the presentation.

\section{Speaking Skill}

From a pragmatic view of language performance, listening and speaking are almost always closely interrelated. While it is possible to isolate some listening performance types, it is very difficult to isolate oral production tasks that do not directly involve the interaction of aural comprehension. Only in limited contexts of speaking can we assess oral language without the aural participation of an interlocutor. While speaking is one of productive skill that can be directly and empirically observed, those observations are invariably colored by the accuracy and effectiveness of a test-takers listening skill, which necessarily compromises the reliability and validity of an oral production test. The interaction of speaking and listening challenges the designer of an oral production test to tease apart, as much as possible, the factors accounted for by aural intake. Another challenge is the design of elicitation techniques. Because most speaking is the product of creative construction of linguistic strings, the speaker makes choices of lexicon, structure, and discourse (Brown, 2004: 140).

Speaking skills are an important part of the curriculum in language teaching, and this makes them an important object of assessment as well. Assessing speaking is challenging, however, because there are so many factors that influence our impression of how well someone can speak a language, and because we expect test scores to be accurate, just and appropriate for our purpose. This is a tall order; in different contexts teachers and testers have tried to achieve all this through a range of different procedures (Luoma, 2004: 1).

English speaking ability is very important for people interaction where people almost speak everywhere and every day through English. In this global era, many people used English as a media of communication and it makes people who come from different countries to be easier in making interaction and communication. As one of international language, English is also being taught in Indonesia both in religious or non-religious institution. As institution of education, Islamic boarding school also has a program of learning English as the way of communication in daily conversation. Speaking is one way to communicate which ideas and though a message orally. To enable students to communicate, we need to apply the language in real communication. According to Gert and Hans (2008: 207), speaking is speech or utterances with the purpose of having intention to be recognized by speaker and the receiver processes the statements in order to recognize their intentions. Yule (2006) stated that speaking is depending on the complexity of the 
information to be communicated; however, the speaker sometimes finds it difficult to clarify what they want to say. Rebecca $(2006: 144)$ stated that speaking is the first mode in which children acquire language, it is part of the daily involvement of most people with language activities, and it is the prime motor of language change. It also provides our main data for understanding bilingualism and language contact.

\section{Literature Review}

Empirical review is the way to get the information and theories about the previous researches that are still currently available. To elaborate a deep understanding of the theories and the information is the main point of the empirical review. This means that the empirical review is a methodology of the previous researches. The empirical review is also to review the study which had been done by the other researchers.

A study was carried out by Kinyanjui, et al (2015) entitled "Classroom Reinforcement Schedules and Their Effectiveness in Selected Kenyan Primary Schools “. The purpose of the study was to determine Classroom Reinforcement Schedules and Their Effectiveness in Selected Kenyan Primary Schools. The study employed a mixed methods design in which both quantitative and qualitative data were collected. The target population teachers and pupils from public primary

schools.

Data was collected by using questionnaires and interview schedules. quantitative data was analyzed using inferential statistics while qualitative data was analyzed by using the thematic and content analysis. The study reported on the use of praise, tangible items such as games and money were also moderately often used by the teachers. The participants also used both continuous reinforcement and partial reinforcement schedules. The study recommends that, schools should enhance token economy programs which have long term effect. Moreover, teachers should deepen their knowledge on token economy programs for academic success. Previous study also had been reported by Khaliq, et al (2016) which was entitled "Role of Reinforcement or Punishment in Learning English Language: A Study at Secondary Level in Southern Punjab Pakistan". The purpose of the study was to find out the role of reinforcement or punishment in learning English language. The population of the study was students of secondary classes in different schools of Dera Ghazi khan, southern Punjab, Pakistan. A five - point likert scale questionnaire tool was used to collect the data from the target population. The collected data were analyzed through SPSS (Statistical Package for Social Sciences) applying tests like descriptive statistics, frequency, mean, standard deviation, analysis of variation etc. The subjects' responses favored the statement that reinforcement serves as motivational force in learning English language. Participant's responses favored the statement that punishment also serves as driving force in learning English language. It is noted from the participant's responses that they are in favor of teacher's role. It is concluded that teacher can enhance the learning process by using reinforcement or applying punishment tool according to the situation. English is a language which is actually an intrinsic stimulated among the learners. Therefore, a teacher must play the role of a facilitator in providing all guidance with related material and the same time must play the strict role as required according to the situation.

In conclusion, based on the empirical reviews abovementioned, it is clearly explained that both of the present study was conducted about reinforcement. However, in this study, the researcher will conduct a study which is about the use of reinforcement for adult learner in teaching writing and speaking skill.

\section{METHODS}

\section{Research Design}

A methodology is needed to solve the problem that raised from research background, the research design that will be used by the researcher is qualitative research which is in the form of case study research. Qualitative research is characteristics by its aims, which relate to understanding some aspects of social life and its methods which (in general) generate words, rather than numbers, as data analysis (Patton and Cochran, 2002).

\section{Setting of the Study}

The setting of the present study will be conducted in Mahasaraswati Denpasar University which is located in Kamboja Street, Denpasar - Bali. The study will be focused on the second semester students who take writing and speaking class. In addition, the researcher also chose some of the teacher who teach writing and speaking skill in the same semester.

\section{Subject of the Research}

The subject of the present study were the teachers and the students of Mahasaraswati Denpasar University. The students will be chosen from the second semester who will get writing and speaking class. Meanwhile, the teacher will be chosen from the teacher who will teach writing and speaking class in the second semester in Mahasaraswati Denpasar University. They were chosen based on the preliminary observation through investigating the teaching and learning process in writing and speaking class. Besides, the teachers who teach writing and speaking in Mahasaraswati Denpasar University use reinforcement in teaching for adult learner.

\section{Object of the Study}

The object of this present study will be the implementation of reinforcement in the writing and speaking class for adult learner. This study will be focused on the teacher preparation before implementing the reinforcement, the students' responses after the implementation of the reinforcement in writing and speaking class, the types of reinforcement that will be used by the teacher in teaching adult learner. 


\section{Data Collection}

In collecting the data, the researcher will use three kinds of data collection, namely, class observation, interviews, and open - ended questionnaire. The researcher will collect the authentic data from those three kinds of data collection. The data will be in the form of descriptive form which will be the result of the administering the instruments.

\section{Data Analysis}

In analyzing the data, the researcher will use the theory from Creswell (2012) which is said that the data analysis will be include in the making conclusion, representing the result in the table, picture and figure to summarize it. The data collection in this present study will be analyzed by interpreting the result of the open - ended questionnaire and the class observation. In the end of the analysis, the researcher will set the conclusion based on the result of the data analysis.

\section{Research Instrument}

Interview will be used to collect the qualitative data. In addition, it also will be used for gaining the data from lecturer which it will be in the form of structured question and use of open - ended question to probe deeply in order to obtain the information which will be needed by the researcher.

\section{RESULTS AND DISCUSSION}

The use of the reinforcement is completely based on the condition, situation, and process of learning. Reinforcement may seem like a simple strategy that all teachers use, in the writing skill, the first respondent said that she always tries to give some reinforcements during the writing class for giving the students motivation during the writing class. Reinforcement in writing subject is really needed to motivate the students to practice writing because some students think that writing is a boring activity. It is also supported by the other respondents; the use of reinforcement can motivate students to practice and learn writing more

In this case, evening class also really need reinforcement in practicing writing. Most of the students in evening class are working students who have working since morning before take the lecture in the evening. In this case, the use of reinforcement is really needed for those students, who get tired after working to starting the writing class. Reinforcement can be one of the solutions to improve student's motivation in practicing writing.

Even though there are so many obstacles and limitations in giving reinforcement, the lecturer always tries to giving reinforcement before during the class. In speaking class, reinforcement frequently giving more than the writing class because writing class longer time than writing class. In this case, reinforcement is very needed in order to make students to be brave in speaking and expressing their idea. The respondent usually gives reinforcement in the beginning of the class, and sometimes in the middle and end of the class also.
This idea is also supported by the other respondent. She also gives more reinforcement in speaking subject especially for the first semester in university. Many students still shock with the speaking class. Some students look inactive in speaking class because of some reasons like afraid to make a mistake in speaking, lack of vocabulary, shy to speak up and the other reasons. So to solve it, the use of reinforcement is really needed in speaking especially in the first semester as their motivation to express their idea in speaking class and speak more than usual.

The teacher or other staff member will want to provide the reinforcement every single time the student uses the target skill or behavior. The goal of continuous reinforcement is to teach students that when they use appropriate behavior, they get rewarded. In order to make this strong connection, the teacher need to be provided immediately following the target skill. When a student feels a genuine connection with a teacher or other student they provide quality feedback to those who will listen Giving reinforcement should be done as natural as possible, and try to give genuine appreciation to our students. So the teacher not really need to prepare specifically about the reinforcement which is going to be used. The student's condition, the hole classroom condition also should be seen when we decide to give the reinforcement. If students' work well, we have to award it well based on what they already done and keep it natural. But sometimes, if the teacher decides to give praise as a reinforcement, the teacher have to think and prepare it well before give it to the students.

During the learning process, all of respondents use so many positive reinforcements to support the learning process. The purpose of positive reinforcement always, and has been to have students actively contributing and learning in the classroom. When students are interested they show up, and any educator knows that is half the battle. When a child experiences positive reinforcement, there is often a greater willingness to exhibit positive behavior. Students who are encouraged to learn and allowed the chance to show off their learned skills.

Verbal or token reinforcement sometimes is given to the students like praise when they done something well for awarding the students about their achievements. It is always given by the respondent to their students. The other respondent stated that she gives positive and negative reinforcement. The positive reinforcement is giving for the students during the speaking and writing class like rewarding. Students who speak more will get more start than the other. The star is used to determine the score in the end of the class. The other positive reinforcement is giving rewarding to the students like using words "Nice", "Good Job", "Good idea". This awarding also affects students' motivation in the learning process.

Not only scoring and award, but simple gesture is also given as the positive reinforcement. Smiling, giving thumb up, good gesture which is done by the teacher also can be the positive reinforcement can be given to the students when they done some their tasks well. Although it is only a 
simple thing, but it is gives big impact for the students especially in speaking and writing skill. When a child's environment becomes a positive atmosphere that takes notice to their positive behavior the child is more likely to be physically and mentally present in the classroom In order for positive reinforcement to become an effective technique in the classroom, teachers must know their students' needs. When teacher gives praise must clearly state the exact positive behavior that the student is exhibiting and comment on its specific effect on academic and/or social achievement.

Negative reinforcements also sometimes given by the teacher in case to improve the students' ability in speaking for example by pointing the students directly to speak up. In this case, pointing is taken when the teacher gives students a chance for expressing their idea but no one students willing to speak up. Negative reinforcement is often, mistakenly, equated with punishment. Punishment is the application of aversive stimuli to reduce the chance of a behavior being repeated. Negative reinforcement is the removal of aversive stimuli to increase the probability of a behavior being repeated. Punishment can be an effective tool to diminish a negative behavior almost immediately, but punishment has been shown to yield fewer results when compared to reinforcing positive behaviors with praise

Negative reinforcement also involves a positive stimulus, but this time this positive stimulus is removed every time an undesired behavior is expressed. For example, every time learners answer incorrectly an online multiple choice question, no extra points are added to their total score, as they do not get rewarded with the extra points assigned to each question (positive stimulus). This removal of desired stimuli serves as feedback to the learners, making them understand that this was not the expected behavior. Therefore, learners who want to improve their score know that they have to study harder and pay more attention to the questions in order to answer correctly and be awarded with all the points they need to pass the test.

\section{CONCLUSION}

The use of the reinforcement is completely based on the condition, situation, and process of learning. Reinforcement may seem like a simple strategy that all teachers use, but it is often not used as effectively as it could be. The purpose of positive reinforcement always, and has been to have students actively contributing and learning in the classroom especially in writing and speaking skill. The teacher or other staff member will want to provide the reinforcement every single time the student uses the target skill or behavior. The goal of continuous reinforcement is to teach students that when they use appropriate behavior, they get rewarded.

Verbal or token reinforcement sometimes is given to the students like praise when they done something well for awarding the students about their achievements simple gesture is also given as the positive reinforcement. Smiling, giving thumb up, good gesture which is done by the teacher also can be the positive reinforcement can be given to the students when they done some their tasks well. Although it is only a simple thing, but it is gives big impact for the students especially in speaking and writing skill.

Negative reinforcements also sometimes given by the teacher. Punishment can be an effective tool to diminish a negative behavior almost immediately, but punishment has been shown to yield fewer results when compared to reinforcing positive behaviors with praise. Negative reinforcement also involves a positive stimulus, but this time this positive stimulus is removed every time an undesired behavior is expressed.

\section{REFERENCES}

Alberto, P. \& Troutman A ., (2006). Applied Behaviour Analysis for Teachers. 7 Edition Upper Saddle River, Prentice Hall Merriel

Bandura, A. (2008). Organizational Application of Social Cognitive Theory.

Australian Journal of Management, Volume 6, 275-302.

Brophy, J. (1988). "Educating Teachers About Managing Classroom and Students". Teaching and Teacher

Education. Vol 4. No 1.(pp.1-18).

Brown, H. D. (2004). Language Assessment Principles and Action Practices. New York: Longman.

Creswell, W. John, (2012). Educational Research Fourth Edition. Pearson Educational: USA

Cotton, C. (2008). Classroom Reinforcement. Herbert Welberg, University of Illinois, Chicago, USA

Evertson, C.M., Emmer, E.T., Clements, B.S., Worsham, M.E. (1997). Classroom Management for Elementry Teacher (4thed.). Boston: Allyn and Bacon.

Glickman, C., \& Tamashiro, R. (1980). Classifying teachers' beliefs about discipline. Educational Leadership, 37(6), 459-464.

Golden, K. and Locke, B. K. D. (2007). Composing Qualitative Research. Canada: Sage Publications, Inc.

Grieser and D. Jerison (2007). Asymptotics of eigenfunctions on plane domains.

Preprint, arXiv:0710.3665,

Kalandadze, M. (2007). English Academic Writing. Budapest: Central European University. 
Kane, T. S. (2000). The Oxford Essential Guide to Writing. New York: Oxford University Press.

Khaliq, et al (2016). Role of Reinforcement or Punishment in Learning English Language: A Study at Secondary Level in Southern Punjab Pakistan. International Journal of Business and Social Science Vol. 7, No. 8 August 2016.

Kinyanjui, et al (2015). Classroom Reinforcement Schedules and Their Effectiveness in Selected Kenyan Primary Schools. Journal of Education and Social Research MCSER Publishing, Rome - Italy.

Knowles, M. S. (1984). Andragogy in Action: Applying Modern Principles of Adult Learning. San Francisco, CA: Jossey-Bass.

Knowles, M. S. (1980)The Modern Practice of Adult Education. Andragogy versus Pedagogy, Englewood Cliffs: Prentice Hall/Cambridge.

Knowles, M. S. (1980). The Modern Practice of Adult Education, rev. ed. Chicago: Association Press/Follett

Lewis, T. and Hurd, S. (2008). Language Learning Strategies in Independent Setting. Canada: Cromwell Press Ltd.

Martin, N., Yin, Z., \& Baldwin, B. (1998). Construct Validation of The Attitudes and Beliefs on Classroom Control Inventory. Journal of Classroom Interaction, 33(2), 6-15.

McNeely, S. R., \& Mertz, N. T. (1990). Cognitive constructs of preservice teachers: research on how student teachers think about teaching. Paper presented at the annual meeting of the American Educational Research Association. Boston, MA.

Moore, Kenneth D. (1989). Classroom Teaching Skills Fifth Edition. New York: McGraw Hill

Moss, D. \& ross-Feldman, L. (2003). Second Language Acquisition in Adults: From Research to Practice. Washington,

DC: National Center for ESL Literacy Education. Available from: http://www.cal.org/Caela/esl_resources/digests/SLA.html

Nunan, D. (2003). Practical English Language Teaching. Singapore: McGraw-Hill

Ogunu M (2000). Introduction to Educational Management. Benin City: Mabogun Publishers

Peace Corp. (2008). Classroom Management. Publication No. M0088
Patton, Q. Michael and Cochran, M. (2002) A Guide Using Qualitative Research Method. London: Medecins Sans Fronteres.

Patel, M. F. and Jain, P. M. (2008). English Language Teaching. Jaipur: Sunrise Publisher \& Distributor.

Slavin, R. (2009). Educational Psychology: Theory and Practice (9th edition).

Pearson International. Columbus, Ohio.

Weinstein, C. S. (1996). Secondary classroom management: Lessons from research and practice. New York: McGraw-Hill.

Wong, H. and Wong, W. (2009). The First Days of School and How To Be an Effective Teacher. Harry K. Wong Publishers Inc. New Jersey

Yule, G. (2006) The Study of Language. New York : Cambridge

Zemach, D. E. and Islam, C. (2005). Paragraph Writing from Sentence to Paragraph. New York: Macmilan Publisher Limited. 